\title{
PENGARUH MODEL PEMBELAJARAN INKUIRI TERBIMBING BERBASIS LITERASI SAINS TERHADAP HASIL BELAJAR MATERI POKOK LARUTAN PENYANGGA
}

\author{
Eka Nurul Qomaliyah, Sukib, I Nyoman Loka
}

\author{
Program Studi Pendidikan Kimia, Jurusan P.MIPA, FKIP, Universitas Mataram, Mataram, Indonesia \\ Email: ekanurulqomaliyah@ymail.com
}

\begin{abstract}
Abstrak. Penelitian ini bertujuan untuk mengetahui pengaruh model inkuiri terbimbing berbasis literasi sains terhadap hasil belajar materi pokok larutan penyangga pada siswa kelas XI SMAN 1 Gunungsari. Desain penelitian yang digunakan adalah quasi experimental dengan rancangan nonequivalent control group design. Populasi penelitian yaitu seluruh siswa kelas XI IPA SMAN 1 Gunungsari yang terdiri dari empat kelas, dengan jumlah total 98 siswa. Teknik pengambilan sampel dalam penelitian ini adalah purposive sampling. Sampel terpilih yaitu kelas XI IPA 1 sebagai kelas eksperimen yang diberi perlakuan model inkuiri terbimbing berbasis literasi sains dan kelas XI IPA 2 sebagai kelas kontrol yang diberi perlakuan model konvensional, yaitu ceramah dan tanya jawab. Hasil uji hipotesis dengan uji Anakova satu jalur dengan satu kovariabel didapatkan Fhitung sebesar 13,91, sedangkan nilai Ftabel dengan probabilita 0,05 sebesar 4,05, maka Fhitung >Ftabel $(13,91>4,05)$ yang menunjukkan ada pengaruh model pembelajaran inkuiri terbimbing berbasis literasi sains terhadap hasil belajar. Nilai rata-rata kelas dan ketuntasan klasikal yang lebih besar pada kelas eksperimen dibandingkan kelas kontrol menunjukkan pembelajaran dengan model inkuiri terbimbing berbasis literasi sains lebih baik dibandingkan dengan pembelajaran konvensional dikaitkan dengan hasil belajar.
\end{abstract}

Kata Kunci: Hasil belajar, Inkuiri Terbimbing, Larutan Penyangga, Literasi Sains

\begin{abstract}
This research aimed to investigate the influence of guided inquiry model based on science literacy to the learning outcomes of the subject matter of the buffer solution of second year student in SMAN 1 Gunungsari. The research used quasi-experimental method with nonequivalent control group design. The population of the research were 98 students of second year science of SMAN 1 Gunungsari, which were divided into four classes. The sampling technique in this research used purposive sampling. XI science-1 class was selected as the experimental class which used guided inquiry model based on science literacy and XI science-2 class was selected as the control class which used conventional models through lectures and question-answer. Hypothesis test results through the Ancova one lane with one covariates test obtained Fcount equal to 13.91, while the value of Ftable with probability 0,05 equal to 4,05, then Fcount > Ftable $(13.91>4.05)$, the results show that there is an influence of guided inquiry learning model. The average and classical completeness value of experimental class greater than the control class shows that guided inquiry based on science literacy learning is better than the conventional learning related to learning outcomes.
\end{abstract}

Key words: Learning Outcomes, Guided Inquiry, Buffer Solution, Science Literacy

\section{PENDAHULUAN}

Keberhasilan proses belajar mengajar dapat diamati melalui hasil belajar siswa. Salah satu permasalahan pembelajaran yang berdampak pada rendahnya hasil belajar siswa adalah kesulitan menerapkan model pembelajaran dalam proses belajar mengajar secara efektif serta pemilihan model pembelajaran yang kurang tepat dalam menyampaikan materi ajar. Proses belajar mengajar tidak hanya menuntut siswa untuk menghafal konsep atau melibatkan kemampuan ingatan saja, namun juga mengaitkan konsep yang dipahami dengan kehidupan sehari-hari atau yang disebut dengan aspek literasi sains [1].

Hasil pencapaian siswa Indonesia pada penilaian PISA menunjukkan rata-rata kemampuan sains peserta didik Indonesia berada pada tahapan terendah (nominal-fungsional). Tahapan nominal fungsional menunjukkan kemampuan menghafal, mengenali sejumlah fakta dasar, akan tetapi belum mampu mengkomunikasikan dan mengaitkan kemampuan itu dengan berbagai topik sains apalagi menerapkannya pada konsep-konsep yang kompleks dan abstak [2]. Hal ini seperti pada pembelajaran kimia yang erat kaitannya dengan kehidupan seharihari yakni materi pokok larutan penyangga. Nilai rata-rata ulangan tengah semester ganjil siswa kelas XI IPA di semester ganjil SMAN 1 Gunungsari pada mata pelajaran kimia masih tergolong rendah karena kurang dari nilai ketuntasan minimal (KKM). Nilai KKM yang ditetapkan di SMA Negeri 1 Gunungsari untuk materi kimia kelas XI-IPA adalah 75. Kesulitan yang dialami oleh sebagian besar siswa kelas XI-IPA SMAN 1 Gunungsari dalam mempelajari kimia karena karakteristik materi kimia kompleks, melibatkan konsep yang cukup abstrak, perhitungan matematik, hukum dan prinsip-prinsip dalam penyelesaian soalnya. Berdasarkan hasil wawancara dengan guru mata pelajaran kimia kelas $\mathrm{XI}$, proses pembelajaran berlangsung dengan dominansi penyampaian lisan melalui ceramah dan penugasan.

Karakteristik materi kimia yang kompleks menyebabkan motivasi, minat dan kemandirian 
belajar kimia siswa kelas XI SMAN 1 Gunungsari terhadap pembelajaran kimia sangat rendah. Siswasiswa cenderung untuk menghafalkan rumus, definisinya saja tanpa ada pemahaman yang mendalam dari suatu materi kimia tersebut. Dalam proses pembelajaran kimia diperlukan sebuah pemahaman yang benar untuk mendukung konsep yang dibangun siswa [3]. Selain itu, mengaitkan konsep yang dibangunnya dengan kehidupan seharihari yang relevan secara konseptual merupakan cara belajar sains yang tepat melalui pemecahan masalahmasalah dalam kehidupan masyarakat [4]. Cara belajar sains dapat diaplikasikan melalui model pembelajaran yang sesuai dengan pembelajaran sainstifik salah satunya yakni model pembelajaran inkuiri terbimbing [5].

Pembelajaran melalui aktivitas yang beragam seperti observasi, penyelesaian masalah dan penarikan kesimpulan merupakan pembelajaran dengan model inkuiri [6,7]. Model pembelajaran inkuiri terbimbing merupakan salah satu jenis model pembelajaran inkuiri [8]. Menurut Cindy [9] melalui inkuri terbimbing siswa dilatih untuk mengembangkan kemampuan berpikir, kerja sama tim dan mempermudah siswa untuk belajar. Selain itu, menurut Dewi [10] model pembelajaran inkuiri terbimbing menekankan siswa untuk aktif, meningkatkan minat, motivasi, dan kemandirian belajaran, melatih keberanian, berkomunikasi dan berusaha mendapatkan pengetahuannya sendiri melalui proses penemuan dan pemecahan masalah. Sanjaya dalam Triyani [11] adapun tahapan model inkuri terbimbing terdiri dari 1)orientasi siswa terhadap materi pelajaran, 2) merumuskan masalah dengan bimbingan guru, 3) merumuskan hipotesis dengan bimbingan guru, 3) mengumpulkan data, 4) menguji hipotesis, 5) menarik kesimpulan dan mengkomunikasikannya.

Pembelajaran yang melibatkan penggunaan sumber belajar yang bervariasi, proses inkuiri dan pengambilan keputusan yang berkaitan dengan kehidupan sehari-hari merupakan konsep pembelajaran berbasis literasi sains. Pembelajaran yang diawali dengan suatu masalah ilmiah, dilanjutkan dengan merumuskan jawaban sementara dan proses penyelidikan untuk menyelesaikan masalah melalui literatur dan kegiatan laboratorium, selanjutnya, pemahaman yang didapat dari proses penyelesaian masalah tersebut, digunakan untuk mengambil keputusan dalam kehidupan sehari-hari. Hal inilah yang dimaksud dengan pembelajaran inkuiri terbimbing berbasis literasi sains.

Berdasarkan uraian tersebut maka tujuan dilaksanakan penelitian ini yakni untuk mengetahui pengaruh penerapan model inkuiri terbimbing berbasis literasi sains terhadap hasil belajar materi pokok larutan penyangga pada siswa kelas XI SMAN 1 Gunungsari.

\section{METODE PENELITIAN}

Penelitian ini dilaksanakan di SMAN 1 Gunungsari semester genap tahun ajaran 2015/2016, pada bulan Januari-Februari 2016. Jenis penelitian yang digunakan adalah Quasy Experimental (eksperimen semu), dengan desain penelitian Nonequivalent Control Group Design (desain kelompok kontrol tidak sepadan). Rancangan atau desain penelitian disajikan pada Tabel 1 .

Tabel 1. Desain Kelompok Kontrol Tidak Sepadan

\begin{tabular}{llll}
\hline Kelas & Pretest & Perlakuan & $\begin{array}{l}\text { Post- } \\
\text { Test }\end{array}$ \\
\hline Kontrol & Ya & $\begin{array}{l}\text { Model } \\
\text { konvensional } \\
\text { melalui } \\
\text { ceramah dan } \\
\text { tanya jawab }\end{array}$ & \\
\hline Eksperimen & Ya & $\begin{array}{l}\text { Model inkuiri } \\
\text { terbimbing } \\
\text { berbasis literasi } \\
\text { sains }\end{array}$ & Ya \\
\hline & & & \\
\hline
\end{tabular}

kelas XI-IPA yang terdiri atas 4 kelas dengan jumlah siswa secara keseluruhan yakni 98 siswa. Teknik pengambilan sampel dengan teknik purposive sampling. Teknik purposive sampling yakni teknik penentuan sampel dengan pertimbangan tertentu [12], sehingga didapatkan kelas XI IPA-1 sebagai kelas eksperimen dan XI IPA-2 sebagai kelas kontrol.

Data yang dikumpulkan dalam penelitian ini terdiri atas data pretest dan post test kedua kelas sampel. Instrumen yang digunakan untuk mendapatkan data tersebut yakni instrument soal pilihan ganda. Instrumen diuji validitas dan realibilitas. Validitas butir soal diuji menggunakan uji korelasi point biserial, sedangkan realibilitas diuji menggunakan uji KR.20. Analisis uji hipotesis menggunakan uji anakova satu jalur satu kovariat, dengan asumsi data yang dikumpul harus terdistribusi normal dan variansnya homogen [13]. Selain data tersebut, terdapat data penunjang berupa data aktivitas belajar siswa melalui observasi rekan sejawat.

\section{HASIL DAN PEMBAHASAN}

Hasil uji coba instrumen dengan validitas butir soal menggunakan teknik korelasi point biserial diperoleh 22 butir soal valid dari 35 butir soal. Selanjutnya, dilakukan uji reliabilitas diperoleh nilai koefesien r11 sebesar 0,77. Nilai r11 dikonsultasikan dengan tabel kriteria reliabilitas, sehingga diperoleh bahwa instrument soal yang digunakan termasuk dalam kriteria reliabilitas tinggi.

Data yang diperoleh dalam penelitian ini adalah data hasil belajar dalam ranah pengetahuan (kognitif) yang dihasilkan dari tes awal (pretest) sebelum dilaksanakan kegiatan pembelajaran dan tes akhir (posttest) yang dilakukan setelah diberi 
perlakuan atau kegiatan pembelajaran materi pokok larutan penyangga. Pretest dan Posttest diikuti oleh masing-masing 25 orang siswa pada kelas eksperimen dan kontrol. Adapun rincian data hasil belajar tersebut disajikan dalam Tabel 2 .

Tabel 2. Data Hasil Belajar Siswa

\begin{tabular}{ccccc}
\hline & \multicolumn{2}{c}{ Pretest } & \multicolumn{2}{c}{ Post-test } \\
\cline { 2 - 5 } & Kelas eksperimen & Kelas kontrol & Kelas eksperimen & Kelas kontrol \\
\hline Nilai rata-rata & 23,40 & 25,76 & 76,92 & 63,48 \\
Nilai tertinggi & 41 & 41 & 95 & 82 \\
Nilai terendah & 9 & 9 & 50 & 32 \\
Ketuntasan klasikal & & & $64 \%$ & $28 \%$ \\
\hline
\end{tabular}

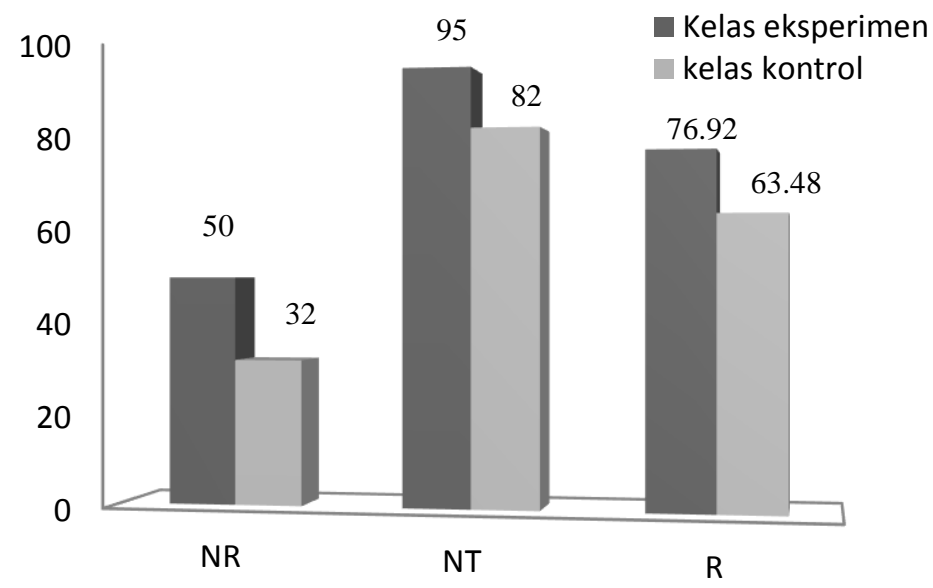

Gambar 1. Perbandıngan nılaı sıswa kelas eksperımen dan kontrol pada hasıl belajar setelah diberikan perlakuan (Post test). NR= Nilai terendah, NT= Nilai tertinggi, $\mathrm{R}=$ Rata-rata nilai

Tabel 3 Ringkasan Uji Anakova Satu Jalur Satu Kovariat

\begin{tabular}{lccccc}
\hline \multicolumn{1}{c}{ Sumber varians } & Jkres & $\mathrm{db}$ & $\mathrm{Rk}$ & Fhitung & Ftabel \\
\hline Antar kelompok & 2398,487 & 1 & 2398,487 & & \\
Dalam kelompok & 8100,639 & 47 & 172,354 & 13,910 & 4,050 \\
Total & 10499,126 & & & &
\end{tabular}

Perbandingan nilai siswa kelas eksperimen dan kontrol pada hasil belajar setelah diberikan perlakuan (Post test) selanjutnya disajikan melalui gambar 1.Data pretest dan post test digunakan untuk menguji hipotesis penelitian dan mengukur pengaruh perlakuan yang diberikan. Uji hipotesis menggunakan uji ANAKOVA satu jalur satu kovariabel. Uji hipotesis dapat dilakukan setelah memenuhi persyaratan asumsi yakni pertama, data terdistribusi normal melalui analisis normalitas uji Chi Kuadrat. Berdasarkan perhitungan diperoleh koefesien normalitas ( $\chi 2$ hitung) data pretest kelas eksperimen sebesar 4,656 dan $\chi 2$ hitung kelas kontrol sebesar 4,472 . Data post test koefesien normalitas ( $(\chi 2$ hitung) kelas eksperimen sebesar 6,296 dan kelas kontrol sebesar 5,184. $\chi 2$ hitung yang diperoleh dikonsultasikan dengan harga $\chi 2$ tabel pada taraf signifikan $5 \%$ yakni sebesar 11,070, sehingga diperoleh $\chi 2$ hitung $\leq \chi 2$ tabel yang berarti bahwa data pretest dan post test kelas eksperimen dan kelas kontrol terdistribusi normal.

Asumsi kedua yang harus dipenuhi yakni varians data homogen melalui uji homogenitas menggunakan uji Fischer (uji F). Berdasarkan hasil perhitungan statistik uji-F diperoleh varians pretest kelas eksperimen yakni 102,750, varians posttest kelas eksperimen yakni 163,820, sedangkan varians pretest kelas kontrol yakni 119,440 , varians posttest kelas kontrol yakni 183,760 . Varians terkecil adalah varians pretest kelas eksperimen, sementara varians terbesar adalah varians posttest kelas kontrol. Dari keempat data tersebut hasil analisis homogenitas diperoleh nilai Fhitung sebesar 1,780, dikonsultasikan dengan harga Ftabel yakni sebesar 1,98. Fhitung < Ftabel, yang berarti bahwa varians data tersebut homogen.

Pengujian hipotesis uji anakova dalam penelitian ini memiliki fungsi untuk melihat pengaruh model pembelajaran inkuiri terbimbing berbasis literasi sains terhadap hasil belajar siswa kelas XI pada 
materi pokok larutan penyangga. Pengujian ini dilakukan dengan mengontrol variabel numerik yang dapat mempengaruhi hasil penelitian. Data pretest digunakan sebagai kovariat dan data post test digunkaan sebagai variat. dan Adapun tabel ringkasan hasil uji anakova dalam penelitian ini disajikan dalam Tabel 4.

Berdasarkan Tabel 3 hasil perhitungan uji anakova diperoleh Fhitung sebesar 13,910, dikonsultasikan dengan Ftabel pada taraf signifikan 5\% dengan db 1:47 sebesar 4,050. Harga Fhitung > Ftabel, maka hipotesis nol (H0) ditolak dan hipotesis alternatif (Ha) diterima, yang artinya setelah dikendalikan oleh kovariat berupa skor pretest terbukti bahwa terdapat pengaruh positif pembelajaran inkuiri terbimbing berbasis literasi sains terhadap hasil belajar materi pokok larutan penyangga di kelas XI SMAN 1 Gunungsari. Pengaruh positif yang dihasilkan dapat disebabkan oleh beberapa faktor yang menguatkan proses pembelajaran melalui penerapan model inkuiri terbimbing berbasis literasi sains dalam penelitian ini. Adapun faktor tersebut terdiri dari tiga yakni aktivitas belajar siswa yang lebih baik, berkembangnya kemampuan berpikir siswa dan adanya penggunaan sumber belajar bervariasi.

Faktor pertama, aktivitas belajar siswa. Berdasarkan lembar observasi aktivitas siswa, pada kelas eksperimen (penerapan model inkuiri terbimbing berbasis literasi sains) memiliki

persentase keaktifan lebih tinggi dibandingkan kelas kontrol. Persentase keaktivan siswa kelas eksperimen dan kelas kontrol berdasarkan lembar observasi masing-masing adalah 76,9\% dan 55,7\%. Adapun aspek-aspek yang dinilai dalam lembar observasi aktivitas siswa yakni antusias siswa dalam mengikuti pelajaran, interaksi siswa dengan guru, interaksi siswa dengan siswa dan partisipasi siswa dalam menyimpulkan pembelajaran.

Tingginya aktivitas belajar siswa kelas eksperimen ini menunjukkan bahwa unsur-unsur model pembelajaran inkuiri terbimbing terlaksana dengan baik. Unsur-unsur tersebut menurut Beamon dalam Lang [14] melibatkan interaksi guru dengan siswa, siswa dengan siswa. Dalam interaksi ini, guru berperan sebagai fasilitator pada tahap merumuskan masalah dan menghubungkan konten pembelajaran dengan permasalahan yang diangkat, sementara siswa secara aktif berdiskusi, mengeksplorasi informasi bacaan atau data. Kegiatan ini dilakukan untuk menyelesaiakan masalah melalui proses investigasi. Selanjutnya, terdapat penugasan tambahan dan pemberian penguatan konsep oleh guru dibagian akhir pembelajaran. Hal ini sesuai dengan penelitian Chase [15] bahwa siswa dalam model pembelajaran inkuiri terbimbing menunjukkan keaktifan yang lebih baik karena ia merupakan subyek belajar utama dan dapat meningkatkan kemampuan sosialnya melalui diskusi kelompok kecil. Selain itu, Haristy [16] dan adolphus [17] bahwa pembelajaran berbasis literasi sains melibatkan partisipasi aktif siswa dalam pembelajaran dan rasa ingin tahu siswa bertambah karena siswa diberikan kesempatan untuk untuk mengenali, menemukan dan mencari tahu berbagai aplikasi sains dalam kehidupan sehari-hari, sehingga siswa akan menyadari bahwa kimia merupakan ilmu pengetahuan yang dekat dengan kehidupan.

Faktor kedua, berkembangnya kemampuan berpikir siswa dalam hal ini berpikir analitis. Siswa kelas eksperimen melalui penerapan model pembelajaran inkuiri terbimbing berbasis literasi sains dilatih untuk berpikir analisis dalam memecahkan suatu permasalahan disetiap pertemuan. Berdasarkan tahapan orientasi pembelajaran yakni merumuskan masalah, merumuskan hipotesis, mengumpulkan informasi atau data, menguji hipotesis dan merumuskan kesimpulan. Tahapan ini sesuai dengan kaidah metode ilmiah, sehingga mampu mengembangkan kemampuan berpikir logis dan analisis. Siswa menganalisis permasalahan serta memilih dan mengumpulkan informasi atau data yang mendukung penyelesaian masalah dalam pembelajaran.

Faktor ketiga, adanya penggunaan sumber belajar yang bervariasi. Pembelajaran inkuiri terbimbing berbasis literasi sains dalam penelitian ini melibatkan penggunaan sumber belajar yang bervariasi. Sumber belajar tersebut diantaranya handout yang berasal dari guru, buku paket siswa dan juga internet yang dapat diakses siswa, sehingga siswa dalam diskusi kelompok dapat saling membagi tugas untuk mencari data melalui sumber-sumber belajar yang telah disiapkan. Penggunaan sumber belajar bervariasi sesuai dengan konsep pembelajaran berbasis literasi sains berdasarkan dimensi kosakata yang berarti dalam pembelajaran diterapkan kegiatan membaca dan memahami bacaan sains dari literaturliteratur terkait guna mengambil keputusan penyelesaian masalah. Melalui penggunaan sumber belajar yang bervariasi kelompok siswa dapat saling memberi penguatan dan berbagi informasi penting sebagai tambahan terhadap suatu pemecahan masalah yang disajikan. Hal ini dapat memperkaya pengetahuan mereka. Sementara dikelas kontrol pembelajaran hanya bersumber dari guru dan handout yang dibagikan guru, sehingga pembelajaran lebih menekankan akan keaktifan guru atau teacher center.

Berdasarkan Gambar 1 dan tabel 2 nilai tertinggi, nilai rata-rata dan ketuntasan klasikan dari penerapan model inkuiri terbimbing berbasis literasi sains belum maksimal, karena belum mencapai skor tertinggi (100). Hal ini disebabkan model pembelajaran bukan merupakan faktor tunggal yang mempengaruhi hasil belajar. Berdasarkan Slameto [18] bahwa hasil belajar dipengaruhi oleh faktor internal dan faktor eksternal. Faktor internal berkaitan dengan kondisi fisik dan psikologis siswa dalam mengikuti pembelajaran. Faktor eksternal berkaitan dengan faktor perhatian orang tua, fasilitas dan cara belajar atau model pembelajaran yang diterapkan disekolah serta faktor masyarakat yang berkaitan dengan keadaan lingkungan siswa yang mendukung 
atau tidaknya siswa untuk siap mengikuti pembelajaran di sekolah. Akan tetapi, dengan pengendalian faktor model pembelajaran melalui model inkuiri terbimbing berbasis literasi sains pada siswa kelas XI SMAN 1 Gunungsari memberikan hasil yang lebih baik dibandingkan dengan penerapan model pembelajaran konvensional yang biasa dilakukan guru. Oleh karena itu, model pembelajaran inkuiri terbimbing berbasis literasi sains merupakan alternatif model pembelajaran yang tepat untuk meningkatkan hasil belajar, keaktifan siswa serta ketuntasan belajar siswa. Dalam pelaksanaannya, model pembelajaran inkuiri terbimbing berbasis literasi sains ini dapat didukung oleh adanya lembar kerja kelompok siswa yang disusun secara sistematis mengikuti tahapan model inkuiri terbimbing, sehingga menuntun siswa mengikuti pembelajaran dengan lebih efektif.

\section{KESIMPULAN}

Berdasarkan hasil penelitian dan pembahasan, maka dapat disimpulkan bahwa penerapan model Inkuiri terbimbing berbasis literasi sains setelah dikendalikan oleh kovariabel (variabel pretest) berpengaruh positif terhadap hasil belajar materi pokok larutan penyangga pada kelas XI SMAN 1 Gunungsari tahun ajaran $2015 / 2016$.

\section{UCAPAN TERIMAKASIH}

Penelitian ini selesai dengan baik karena bantuan berbagai pihak. Penulis mengucapkan terimakasih untuk dosen pendidikan kimia FKIP Universitas Mataram untuk bimbingan dan arahan selama penelitian serta pihak sekolah SMAN 1 Gunungsari untuk ijin dan arahannya dalam pelaksanaan penelitian ini.

\section{DAFTAR PUSTAKA}

[1] Suciati, Resty. 2011. Identifikasi Kemampuan Siswa dalam Pembelajaran Biologi ditinjau dari aspek literasi sains. Jurnal FKIP UNS. Vol. 1 No.1.

[2] Toharuddin, Uus, Hendrawati dan Rustaman. 2011. Membangun Literasi Sains Peserta Didik. Bandung : Humaniora.

[3] [3] Purwaningtyas, Rastiana, Ashadi dan Suparmi. 2012. Pembelajaran Kimia Menggunakan Pendekatan Sains Teknologi Masyarakat dengan Metode Proyek dan Metode Eksperimen Ditinjau dari Kreativitas dan Berpikir Kritis. Jurnal Inkuiri UNS Vol. 1 No.1.

[4] Tanree, M. 2008. Environment Problem In Learning Chemistry for High School Students. Journal of Applied Science In Environmental Sanitation. Vol. 3 No.1.
[5] Sani, R. 2014. Pembelajaran Sainstifik. Jakarta : PT Bumi Aksara.

[6] National Research Council. 2000. Inquiry and The National Science Education Standard A Guided for Teaching and Learning. Washington DC: National Academy Press.

[7] Yasmin, N., Ramdani, A., \& Azizah, A. 2015. Pengaruh metode inkuiri terbimbing terhadap keterampilan proses sains dan hasil belajar biologi siswa kelas VIII di SMPN 3 Gunungsari tahun ajaran 2013/2014. Jurnal pijar MIPA, 10(2).

[8] Zulfiani, T.G. 2009. Strategi Pembelajaran Sains. Jakarta : Lembaga Pusdakarya.

[9] Cindy, Ravit Golan and Clarck A Chinn. 2006. Scaffolding and Achievment in Problem Based and Inquiry Learning: A Reponse to Krischner, Sweller and Clarck. Journal of Education Psychologist. Vol. 42 No.2

[10] Dewi, Nyoman Dantes dan I Wayan Sadia. 2013. Pengaruh Metode Pembelajaran Inkuiri Terbimbing Terhadap Sikap Ilmiah dan Hasil Belajar IPA. e-journal Program Pascasarjana Universitas Pendidikan Ganesha. Vo.3 No.1.

[11] Triyani, D.N. 2014. Analisis Penilaian Portofolio dalam Model Pembelajaran Inkuiri Terbimbing Pada Mata Pelajaran Kimia. Skripsi. UIN Syarif Hidayatullah-Jakarta.

[12] Sugiyono. 2011. Metode Penelitian Pendidikan (Pendekatan Kuantitaif, Kualitatif dan $R \& D)$. Bandung : Alfabeta.

[13] Koyan, I Wayan. 2012. Buku Ajar 2012 Statistika Dua "Analisis Varians, Kovarians, dan Jalur. Bali : Universitas Ganesha Press.

[14]Lang, Hallmut. 2008. Models Strategies and Methods For Effective Teaching. Unted States of America: Pearson Education.

[15] Chase, Anthony, Deblina Parkhira and Marilyne Stain. 2013. Implementing Process-Oriented, Guided Inquiry Learning for the First time: Adaptations and Short-term Impact on Students Attitude and Performance. Journal of Chemical Education. Vol. 90 No.1.

[16] Haristry, Enawati, Eni. 2013. Pembelajaran Berbasis Literasi Sains Pada Materi Larutan Elektrolit dan Nonelektrolit SMA Negeri 1 Pontianak. Artikel. Pendidikan Kimia FKIP Untan.

[17] Adolphus, Telima and A.A Rokoyu. 2012. Improving Scientific Literacy among Secondary School Students through Integration of Information and Communication Technology. ARPN Journal of Science and Techonolgy. Vol.2 No.5.

[18] Slameto. 2003. Belajar dan Faktor-faktor yang Mempengaruhinya. Jakarta : Raneka Cipta. 